\title{
原著 VII
}

\section{直腸癌における神経浸潤に関する病理組織学的検討}

\author{
東京女子医科大学第 2 外科 (主任: 浜野恭一) \\ 鈴 木 啓子
}

\begin{abstract}
直腸癌において脈管系のほかに，神経系を介する進展形式が存在すると考えられているが， 直腸癌118例を対象に神経浸潤に関する病理組織学的な検討を行った. 神経浸潤は $27.1 \%$ に認 められ, 神経線維束内浸潤と神経周囲間隙浸潤が認められた。 神経浸潤と他因子との関係を偏 相関分析で検討したところ, 肉眼所見では肉眼分類が強い相関関係をもっていた. 病理組織学 的所見ではリンパ管侵襲およびリンパ節転移が強い相関関係をもち, 神経浸潤とリンパ流との 関係が示唆された，局所再発は神経浸潤陰性例の $14.0 \%$ に対し神経浸潤陽性例では $37.5 \%$ と有 意に高頻度で認められ $(\mathrm{p}<0.01)$ ，特に神経周囲間隙浸潤陽性例ではその頻度が高かった。 生存率においても, 神経浸潤陽性例では有意に低く $(\mathrm{p}<0.001)$, リンハ節転移を認めない場 合においても神経浸潤陽性例では生存率が低く, 神経浸潤は予後規定因子のひとつであると考 えられた。
\end{abstract}

索引用語 : 直腸癌, 神経浸潤, 局所再発, 生存率, 偏相関分析

\section{緒言}

神経浸潤に関する研究は, 神経叢が密に分布し ている膵癌や胆管癌において多く行われ，膵癌で は後腹膜腔局所再発を生じるひとつの重要な再発 規定因子であると考えられている.さらに膵癌に おいて膵外神経叢を連続的に癌細胞が浸潤してい く, 神経系を介する進展形式の存在が報告されて いる.

一方, 直腸癌においても, リンパ管・血管など の脈管系を介する転移・進展形式のほかに, 直腸 周囲には神経組織が密に分布しており, 膵癌と同 様にそれら神経系を介する進展形式が存在すると 考えられている. 最近では直腸癌に対して, 自律 神経温存術式が盛んに行われるようになってきた が，この術式では自律神経損傷を防止する反面， 癌細胞が遺残する危険性がある，さらに神経組織 自体に癌細胞が浸潤している可能性もあり，その 適応には十分な検討が必要である。また神経系を
介する進展形式が存在するとすれば，局所再発お よび予後に影響を及ぼす可能性が高いと推测され る.

以上の観点から著者は, 直腸癌における神経浸 潤に関し, 治癒切除直腸癌症例118例を対象とし て病理組織学的な検討を行った。 その結果神経浸 潤は確かに存在し，その浸潤形式は神経線維束内 浸潤と神経周囲間隙浸潤とに分けられることを確 かめた．さらに神経浸潤と病理学的諸因子との統 計学的相関, 局所再発率, 予後との関係について 検乱を行い, 神経浸潤の生物学的特性, および自 律神経温存術式に関連した臨床的意義について若 干の知見を得たので報告する.

\section{I. 対象および方法}

\section{1. 対象}

1987年 4 月から1992年 3 月までに東京女子医科 大学第二外科で施行された直腸癌手術症例 140 例 のうち, 追跡調查の明らかな治癒切除症例118例 
表 1 対象

\begin{tabular}{c|c|c}
\hline $\begin{array}{c}\text { 全症例 } \\
\text { 男 }\end{array}$ & $\begin{array}{c}118 \text { 例 } \\
68 \text { 例 }\end{array}$ & 平均年令61.42歳 \\
女 & 50 例 & \\
\hline 占居部位 & $\mathrm{Rs}$ & 30 例 \\
& $\mathrm{Ra}$ & 31 例 \\
& $\mathrm{Rb}$ & 57 例 \\
\hline Dukes 分類 & $\mathrm{A}$ & 37 例 \\
& $\mathrm{B}$ & 32 例 \\
& $\mathrm{C}$ & 49 例 \\
\hline
\end{tabular}

を対象とした。内訳は，男性68例，女性50例，平 均年令 61.42 歳 (23 84歳), 腫痬の占居部位は Rs 30例， Ra 31例，Rb 57例であった（表 1 ). 組織型は高分化腺癌49例，中分化腺癌56例，低分 化腺癌 8 例, 粘液癌 5 例, 壁深達度は $\mathrm{m} 3$ 例, $\mathrm{sm} 7$ 例, pm 36例, ss $\left(\mathrm{a}_{1}\right) 34$ 例, $\mathrm{s}\left(\mathrm{a}_{2}\right) 38$ 例, Dukes 分類では, DukesA 37例, DukesB 32例, DukesC 49例であった. また再発は局所 再発が24例, 肝転移が 8 例であった.

2. 方法

(1) 標本作成

切除標本を 48 時間 $10 \%$ ホルマリン液で固定した 後, 腫瘍中心部を通る腸管縦軸方向の 2 切片を作 成し，通常の hematoxyline-eosin (HE) 染 色に加えて，神経線維を明確にするため S - 100 蛋 白染色標本を作成した。また神経構造の判別困難 な症例に対しては Masson-野口染色やPAM 染色を追加した．観察は腫瘍部位およびその周囲 の正常組織を含めて行った.

(2) 神経浸潤の病理組織学的分類法

神経浸潤にはその分布 (Meissner 神経叢, Auerbach 神経叢のみならず，漿膜下や粘膜下 など）の地理的な関係，浸潤程度，さらに神経線 維束内外の別がある，前者に関しては腫瘍部位お よび腫瘍周囲で，かつ Auerbach 神経叢を中心 に観察し，浸潤程度は観察幅を固有筋層における 横幅 $10 \mathrm{~mm}$ 当たりの浸潤神経の個数により, NI 0 ～NI 3 (NI 0 は 0 個, NI 1 は 1 2 個, NI 2 は $3 \sim 4$ 個，NI 3 は 5 個以上）までの 4 段階に 分類した。後者に関しては, 癌細胞が神経鞘内で かつ神経線維束内に浸潤している場合を神経線維 束内浸潤 (INI) とし, 神経鞘内でかつ神経線維 束外に浸潤している場合を神経周囲間隙浸潤
（PNI）と定義し，2 通りの浸潤形式に分類し， これらそれぞれを神経浸潤陽性と判断した（図 1 ).

(3) 検討項目

I . 神経浸潤陽性率

神経浸潤の陽性率について，浸潤程度および浸 潤形式により検討した.

II. 神経浸潤と肉眼所見および病理組織学的所見 との相関

相関関係の解析には単相関分析, 偏相関分析お よびカイ二乗検定を用い，危険率 $5 \%$ 以下をもっ て有意差ありとした。

1. 肉眼所見と神経浸潤

占居部位, 肉眼分類, 腫瘍径, 環周度について 神経浸潤の有無, 程度および浸潤形式との関係を 検討した。

2. 病理組織学的所見と神経浸潤

組織型，壁深達度，INF，リンパ管侵襲，静脈 侵襲、リンパ節転移について神経浸潤の有無, 程 度および浸潤形式との関係を検討した。

3 。局所再発と神経浸潤

局所再発に関し神経浸潤の有無, 程度, 浸潤形 式との関係, および一般的に自律神経温存術式の 適応を決めるにあたって用いられている壁深達 度, リンパ節転移との関係を含め検討した。

4. 予後之神経浸潤

5 年累積生存率を以下の 3 通りについて Kaplan-Meier 法で算出し, Logrank 法でそれ ぞれ検定を行った。

a) 神経浸潤の有無別の生存率

b）壁樑達度よりみた神経浸潤陽性群および陰性 群の生存率

c）リンパ節転移の有無による神経浸潤陽性群お よび陰性群の生存率

\section{II. 結 果}

\section{1. 神経浸潤陽性率}

神経浸潤は，直腸癌118例のうち32例（27.1 \%)に認められた。浸潤部位は多くが腫瘍内で あったが，3例では腫瘍周囲の神経にも浸潤を認 めた.

神経浸潤の程度は, NI 0 は86例 (72.9\%), NI 1 は20例 (16.9\%)，NI 2 は 6 例(5.1\%), NI 3 

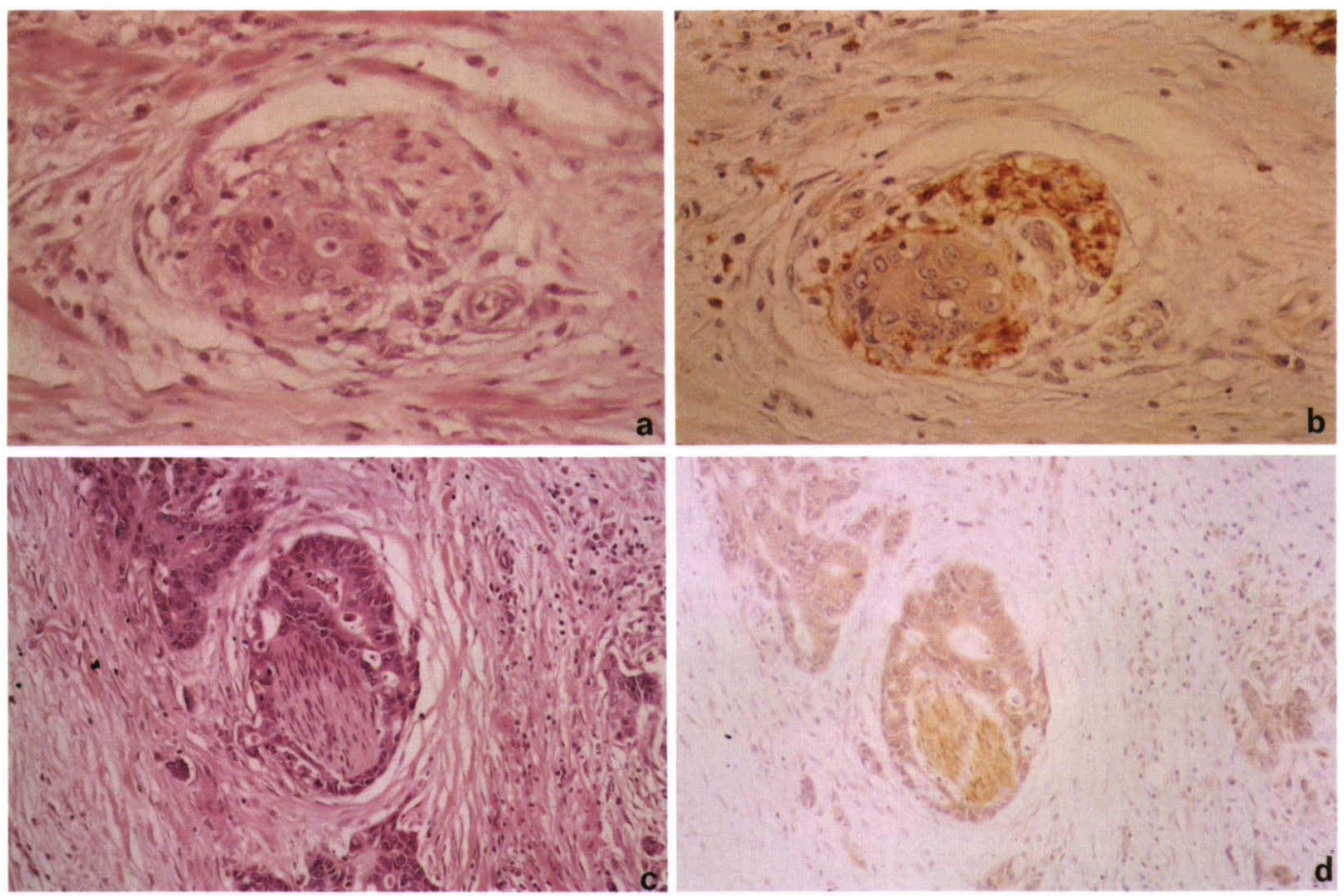

図 1 神経浸潤像

(a) 神経線維束内浸潤 H. E 染色 $(\times 400)$

（b）神経線維束内浸潤 S-100䖯白染色（黄色に染色されている部分が神経線維）

(c) 神経周囲間除浸潤 H.E 染色 $(\times 300)$

（d）神経周囲間鄍浸潤 S-100蛋白染色

表 2 神経浸潤の分類

\begin{tabular}{lllr}
\hline 分類項目 & 分類 & 定義 & \multicolumn{1}{l}{ 症例数 } \\
\hline 浸潤程度 & NI 0 & 浸潤神経数 0 個 & $86(72.9 \%)$ \\
& NI 1 & $1 \sim 2$ & $20(16.9 \%)$ \\
& NI 2 & $3 \sim 4$ & $6(5.1 \%)$ \\
& NI 3 & $5 \sim$ & $6(5.1 \%)$ \\
\hline 浸潤形式 & INI & 神経線維束内浸潤 & $25(21.2 \%)$ \\
& PNI & 神経周囲間隙浸潤 & $7(5.9 \%)$ \\
& & &
\end{tabular}

は 6 例 $(5.1 \%)$ であった.

浸潤形式ではINIのみを認めた症例は25例 (21.2\%), PNI を認めた症例は 7 例 (5.9\%)

であり,このうち 5 例は PNI とともに INI を認 めた（表 2 ).

2. 神経浸潤と肉眼所見および病理組織学的所見

(1) 肉眼所見と神経浸潤（表 3 ）

1) 占居部位

神経浸潤は Rs では30例中 8 例 $(26.7 \%), \mathrm{Ra}$ 31 例中 11 例 $(35.5 \%), \mathrm{Rb} 57$ 例中 13 例 $(22.8$ \%)に認められ，Raが最も多いが，各部位にお
ける浸潤程度による統計学的有意差はなかった。 また浸潤形式では Ra において PNI の頻度が高 い傾向であった。

2 ) 肉眼分類

腫瘍組織を非浸潤型（ $0 ， 1 ， 2$ 型）上浸潤型 （3，4，5型）とに分類した場合, 非浸潤型で は104例中22例（21.2\%）に神経浸潤を認めた。 しかし浸潤型では14例中10例 $(71.4 \%)$ と高率で あり，有意に浸潤型において神経浸潤率は高かっ た $(\mathrm{p}<0.01)$. しかし浸潤程度, 浸潤形式では 差を認めなかった.

3) 腫瘍径

$2.0 \mathrm{~cm}$ 以下では 9 例中 1 例 $(11.1 \%), 2.1 \mathrm{~cm} \sim 4.0$ $\mathrm{cm}$ では51例中 10 例 $(19.6 \%), 4.1 \sim 6.0 \mathrm{~cm}$ では 35 例中 11 例 $(31.4 \%), 6.1 \mathrm{~cm}$ 以上では 23 例中 10 例 （43.5\%）に神経浸潤を認め, 腫瘍径の増加に伴 い浸潤率は増加する傾向にあったが, 有意差は認 められなかった。 浸潤程度および浸潤形式との間 にも差を認めなかった. 
表 3 肉眼所見上神経漫潤

\begin{tabular}{|c|c|c|c|c|c|c|}
\hline & \multirow[b]{2}{*}{ NI (+) } & \multicolumn{3}{|c|}{ 浸閵程度 } & \multicolumn{2}{|c|}{ 浸潤形式 } \\
\hline & & NI 1 & NI 2 & NT 3 & INI & PNI \\
\hline \multicolumn{7}{|l|}{ 占屈部隹. (N. S) } \\
\hline $\mathrm{Rs}$ & $8(26.7 \%)$ & 4 & 2 & 2 & 7 & 1 \\
\hline $\mathrm{Ra}$ & $11(35.5 \%)$ & 6 & 2 & 3 & 7 & 4 \\
\hline $\mathrm{Rb}$ & $13(22.8 \%)$ & 10 & 2 & 1 & 11 & 2 \\
\hline \multicolumn{7}{|l|}{ 肉眼分類 $(p<0.01)$} \\
\hline 非浸澗型 & $22(21.2 \%)$ & 14 & 4 & 4 & 17 & 5 \\
\hline 浸潤型 & $10(71.4 \%)$ & 6 & 2 & 2 & 8 & 2 \\
\hline \multicolumn{7}{|l|}{ 腄瘎径 (N.S) } \\
\hline$\sim 2.0 \mathrm{~cm}$ & $1(11.1 \%)$ & 0 & 1 & 0 & 1 & 0 \\
\hline $2.1 \sim 4.0$ & $10(19.6 \%)$ & 6 & 2 & 2 & 7 & 3 \\
\hline $4.1-6.0$ & $11(31.4 \%)$ & 8 & 1 & 2 & 9 & 2 \\
\hline $6.1 \sim$ & $10(43.5 \%)$ & 6 & 2 & 2 & 8 & 2 \\
\hline \multicolumn{7}{|l|}{ 瞏周度 $(p<0.01)$} \\
\hline $1 / 3$ 以下 & $5(20.0 \%)$ & 3 & 2 & 0 & 5 & 0 \\
\hline $2 / 3$ 以下 & $10(19.6 \%)$ & 8 & 1 & 1 & 6 & 4 \\
\hline 业全周 & $7(33.3 \%)$ & 3 & 2 & 2 & 6 & 1 \\
\hline 全清 & $10(47.6 \%)$ & 6 & 1 & 3 & 8 & 2 \\
\hline
\end{tabular}

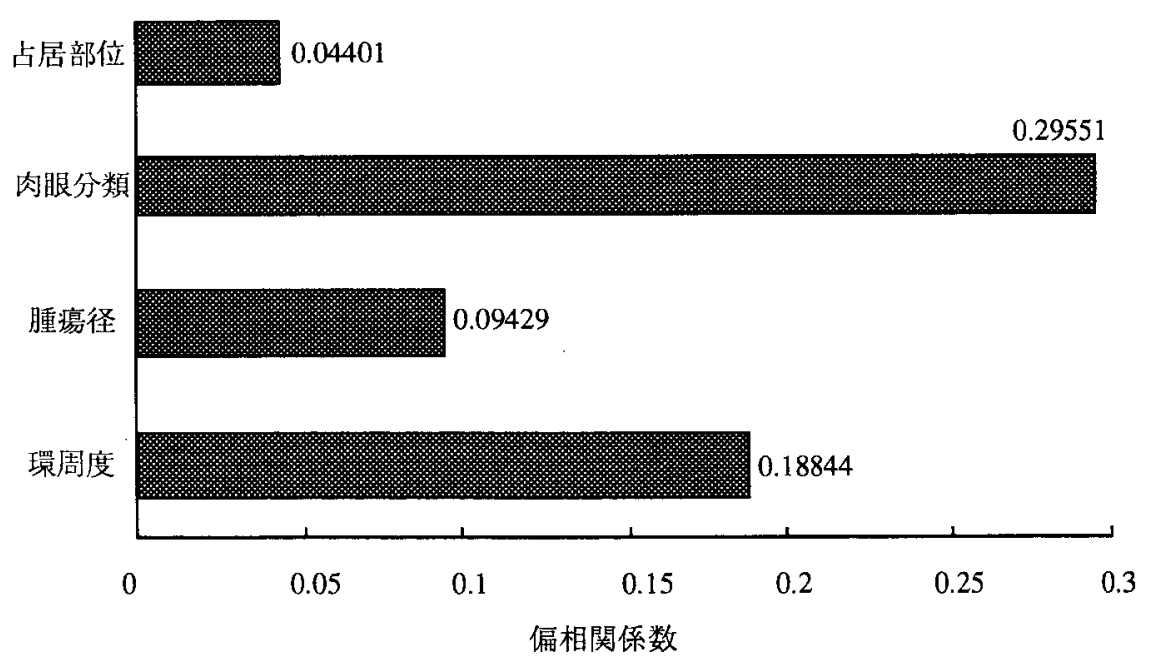

図 2 肉眼所見と神経浸潤との偏相関係数

4) 環周度

腸管に対する腫瘍の占める割合は，1/3 周以 下では25例中 5 例 $(20.0 \%) ， 2 / 3$ 周以下では51 例中10例 $(19.6 \%)$, 亚全周性では21例中 7 例 (33.3\%), 全周性では21例中10例 $(47.6 \%)$ に神経 浸潤を認め，環周度が大きくなるにしたがい神経 浸潤率は有意に増加した $(p<0.01)$ 。また浸潤 程度についても環周度が大きくなるにつれ NI 3 の割合が増加したが，浸潤形式では差を認めな かった。
以上より肉眼所見において，肉眼分類で浸潤 型, 環周度で亜全周性以上の症例で有意に高頻度 で神経浸潤を認めた。さらに偏相関分析により神 経浸潤に関与する因子を検討したところ，肉眼分 類の偏相関係数が最も高く 0.29551 , ついで環周 度で0.18844であり, さらに腫湯径, 占居部位の 順であった（図2）。

(2) 病理組織学的因子と神経浸潤

1) 組織型

高分化腺癌では49例中10例 $(20.4 \%)$, 中分化 
表 4 組織型と神経浸潤

\begin{tabular}{|c|c|c|c|c|c|c|c|}
\hline \multirow{2}{*}{\multicolumn{2}{|c|}{ 組織型 }} & \multirow[b]{2}{*}{$\mathrm{NI}(+)$} & \multicolumn{3}{|c|}{ 浸潤程度 } & \multicolumn{2}{|c|}{ 浸潤形式 } \\
\hline & & & NI 1 & NI 2 & NI 3 & INI & PNI \\
\hline 高分化腺癌 & (49例) & $10(20.4 \%)$ & 7 & 2 & 1 & 8 & 2 \\
\hline 中分化腺癌 & (56例) & $17(30.4 \%)$ & 10 & 3 & 4 & 12 & 5 \\
\hline 低分化腺癌 & ( 8 例) & $5(62.5 \%)$ & 3 & 1 & 1 & 5 & 0 \\
\hline 粘液癌 & ( 5例) & 0 & 0 & 0 & 0 & 0 & 0 \\
\hline
\end{tabular}

表 5 壁深達度と神経浸潤

\begin{tabular}{|c|c|c|c|c|c|c|c|}
\hline \multirow{2}{*}{\multicolumn{2}{|c|}{ 壁深達度 }} & \multirow[b]{2}{*}{$\mathrm{NI}(+)$} & \multicolumn{3}{|c|}{ 浸潤程度 } & \multicolumn{2}{|c|}{ 浸潤形式 } \\
\hline & & & NI 1 & NI 2 & NI 3 & INI & PNI \\
\hline sm以下 & (10例) & 0 & 0 & 0 & 0 & 0 & 0 \\
\hline $\mathrm{pm}$ & (36例) & $4(11.1 \%)$ & 3 & 1 & 0 & 3 & 1 \\
\hline ss $\left(a_{1}\right)$ & (34例) & $10(29.4 \%)$ & 6 & 2 & 2 & 7 & 3 \\
\hline$s\left(a_{2}\right)$ 以上 & (38例) & $18(47.4 \%)$ & 11 & 3 & 4 & 15 & 3 \\
\hline
\end{tabular}

腺癌では56例中17例（30.4\%），低分化腺癌では 8 例中 5 例 $(62.5 \%)$ に神経浸潤を認め, 分化度 の低下にしたがい浸潤率は増加する傾向であっ た. 浸潤程度は高分化腺癌に対し中分化, 低分化 腺癌ではNI 3 の割合が増加する傾向であった が，浸潤形式では有意な差を認めなかった（表 $4)$.

\section{2) 壁樑達度}

$\mathrm{m}$ および sm では神経浸潤は認められなかっ た. pm では36例中 4 例 $(11.1 \%)$, ss $\left(\mathrm{a}_{1}\right)$ で は34例中 10 例 $(29.4 \%), \mathrm{s}\left(\mathrm{a}_{2}\right)$ 以上では38例 中18例 $(47.4 \%)$ に認め, 壁深達度が進むにつれ 浸潤率は有意に増加し，浸潤程度においても壁深 達度とともに增加した $(\mathrm{p}<0.01)$. しかし浸潤 形式では特に関係を認めなかった（表 5 ).

3) $\mathrm{INF}$

INF $\alpha$ では23例中 1 例 $(4.3 \%), \beta$ では77例 中23例 $(29.9 \%), \gamma$ では18例中 8 例 $(44.4 \%)$ に神経浸潤が認められ，増殖様式が強くなるにし たがい有意に神経浸潤率は増加した $(\mathrm{p}<0.05)$. 浸潤程度では INF $\alpha$ に比し $\beta, \quad \gamma$ では NI 2 以上の割合が高かった。浸潤形式においても増 殖様式が強くなるにしたがい PNI の割合が高く なった（表 6 ).

\section{4) 脈管侵襲}

リンパ管侵襲との関係は, $1 \mathrm{y}_{0}$ では58例中 6 例 $(10.3 \%), \mathrm{ly}_{1}$ では33例中 8 例 $(24.2 \%), \mathrm{ly}_{2}$
では16例中 9 例 $(56.3 \%), \mathrm{Iy}_{3}$ では11例中 9 例 (81. 8\%) に神経浸潤が認められ，リンパ管侵襲 が強くなるにしたがい神経浸潤率は有意に増加 し，浸潤程度も強くなった $(\mathrm{p}<0.01)$. 浸潤形 式ではリンパ管侵襲が強いものにおいて PNIを 多く認めた（表 7 ).

静脈侵襲との関係は， $\mathrm{v}_{0}$ では 90 例中 21 例 $(23.3 \%), \mathrm{v}_{1}$ では20例中 7 例 $(35.0 \%), \mathrm{v}_{2}$ で は 7 例中 4 例 $(57.1 \%)$ に認められた。 しかしv では神経浸潤を認めなかった。静脈侵襲の程度に よりわずかに神経浸潤率が増加する傾向は見られ たが，浸潤程度および浸潤形式との間には有意な 差を認めなかった（表 8 )。

5) リンパ節転移

$\mathrm{n}_{0}$ では69例中10例 (14.5\%), $\mathrm{n}_{1}$ は31例中11 例 $(35.5 \%), \mathrm{n}_{2}$ は15例中 9 例 $(60.0 \%), \mathrm{n}_{3}$ 以 上では 3 例中 2 例 $(66.7 \%)$ に神経浸潤を認め, リンパ節転移が強くなる程神経浸潤率は増加し浸 潤程度も強くなった（ $\mathrm{p}<0.01 ）$. 浸潤形式で は，INI でリンパ節転移陽性例が25例中 16 例 (64.0\%) であったのに対し，PNI では 7 例中 6 例 (85.7\%) と高率であり；神経浸潤の中でも 特に PNI がリンパ節転移に高い相関を示してい た（表 9).

以上より病理組織学的所見之神経浸潤之の関係 は，静脈侵襲以外においてそれぞれ有意差のある 相関関係を認めたが，中でも壁深達度，リンパ管 
表 6 INF と神経浸潤

\begin{tabular}{|c|c|c|c|c|c|c|c|}
\hline & \multirow[b]{2}{*}{ INF } & \multirow[b]{2}{*}{ NI. $(t)$} & \multicolumn{3}{|c|}{ 浸潤程度 } & \multicolumn{2}{|c|}{ 浸潤形式 } \\
\hline & & & NI 1 & NI 2 & NI 3 & INI & PNI \\
\hline$\alpha$ & (23例) & $1(4,3 \%)$ & 1 & 0 & 0 & 0 & 1 \\
\hline$\beta$ & (77例) & $23(29.9 \%)$ & 14 & 4 & 5 & 20 & 3 \\
\hline$\gamma$ & (18(例) & $8(44.4 \%)$ & 5 & 2 & 1 & 5 & 3 \\
\hline
\end{tabular}

表 7 リンパ管信襲と神経浸潤

\begin{tabular}{|c|c|c|c|c|c|c|}
\hline \multirow[b]{2}{*}{ リンパ管侵襲 } & \multirow[b]{2}{*}{ NI $(+)$} & \multicolumn{3}{|c|}{ 浸潤程度 } & \multicolumn{2}{|c|}{ 浸潤形式 } \\
\hline & & NI 1 & NI 2 & NI 3 & INI & PNI \\
\hline$l y_{0}(58$ 例 $)$ & $6(10.3 \%)$ & 3 & 1 & 2 & 5 & 1 \\
\hline $\mathrm{ly}_{1}(33$ 例) & $8(24.2 \%)$ & 7 & 1 & 0 & 7 & 1 \\
\hline$l \mathrm{y}_{2}(16$ 例) & $9(56.3 \%)$ & 6 & 2 & 1 & 7 & 2 \\
\hline$l_{y_{3}}(11$ 例) & $9(81.8 \%)$ & 4 & 2 & 3 & 6 & 3 \\
\hline
\end{tabular}

表 8 静脈侵襲と神経浸潤

\begin{tabular}{|c|c|c|c|c|c|c|}
\hline \multirow[b]{2}{*}{ 静脈侵襲 } & \multirow[b]{2}{*}{$\mathrm{NI}(+)$} & \multicolumn{3}{|c|}{ 浸潤程度 } & \multicolumn{2}{|c|}{ 浸潤形式 } \\
\hline & & NI 1 & NI 2 & NI 3 & INI & PNI \\
\hline $\mathrm{v}_{0}(90$ 例) & $21(23.3 \%)$ & 14 & 3 & 4 & 17 & 4 \\
\hline $\mathrm{v}_{1} \quad(20$ 例 $)$ & $7(35.0 \%)$ & 3 & 2 & 2 & 5 & 2 \\
\hline $\mathrm{v}_{2}(7$ 例 $)$ & $4(57.1 \%)$ & 3 & 1 & 0 & 3 & 1 \\
\hline$v_{3}(1$ 例 $)$ & 0 & 0 & 0 & 0 & 0 & 0 \\
\hline
\end{tabular}

表 9 リンパ節転移と神経浸潤

\begin{tabular}{|c|c|c|c|c|c|c|}
\hline \multirow[b]{2}{*}{ リンパ節転移 } & \multirow[b]{2}{*}{$\mathrm{NI}(+)$} & \multicolumn{3}{|c|}{ 浸潤程度 } & \multicolumn{2}{|c|}{ 浸潤形式 } \\
\hline & & NI 1 & NI 2 & NI 3 & INI & PNI \\
\hline $\mathrm{n}_{0}$ (69例) & $10(14.5 \%)$ & 5 & 4 & 1 & 9 & 1 \\
\hline $\mathrm{n}_{1}$ (31例) & $11(35.5 \%)$ & 9 & 0 & 2 & 8 & 3 \\
\hline $\mathrm{n}_{2}$ (15例) & $9(60.0 \%)$ & 5 & 2 & 2 & 7 & 2 \\
\hline $\mathrm{n}_{3}(3$ 例) & $2(66.7 \%)$ & 1 & 0 & 1 & 1 & 1 \\
\hline
\end{tabular}

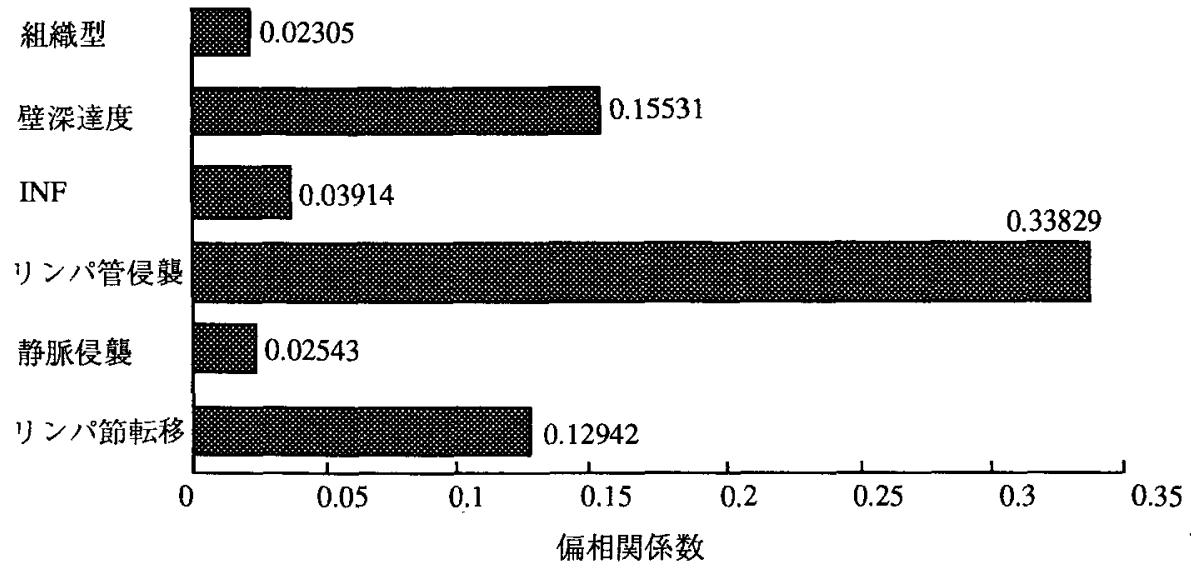

図 3 病理組織学的所見におりる偏相関係数

侵襲，リンパ節転移において強い相関関係を認め た. また偏相関分析により各因子の偏相関係数 をみると，神経浸潤に関与する要因はリンパ管 侵襲が 0.33829 と最も高く,ついで壁深達度で 0.15531 ，リンパ節転移0.12942であった。しか L, INF は0.03914, 静脈侵襲は0.02543, 組織 型は0.02305とここれらの因子との間には相関関 係を䜑めなかった（図 3 )。

(3) 局所再発之神経浸潤

局所再発は118例中24例（20.3\%）に認められ た。神経浸潤陽性群では32例中 12 例（37.5\%） に，陰性群では86例中12例 (14.0\%) に認めら れ，神経浸潤陽性群において局所再発の頻度は有 意に高かった $(\mathrm{p}<0.01)$. 浸潤程度ではNI 1 は20例中 8 例 $(40.0 \%), \mathrm{NI} 2$ は 6 例中 2 例
(33.3\%), NI 3 は 6 例中 2 例 (33.3\%) に局所 再発を認めたが, 各々に有意差は認められなかっ た. 浸潤形式では，INIのみは25例中 8 例 (32.0 $\%)$ PNI を認める症例では 7 例中 4 例 (57.1 \%)に局所再発を認め，PNIにおいて局所再発 の発生頻度が高かった（表10）。局所再発症例に おける壁樑達度との関係は, pm の場合神経浸潤 を認めない症例では32例中 2 例 $(6.3 \%)$ の局所 再発率であるのに対し，神経浸潤陽性例では 4 例 中 1 例 (25.0\%), ss では神経浸潤陰性例24例中 6 例 $(25.0 \%)$ に対し, 陽性例では10例中 4 例 $(40.0 \%), \mathrm{s}$ 以上では陰性例20例中 4 例 $(20.0$ \%）に対し，陽性例18例中 7例 (38.9\%) と明ら かに神経浸潤を認める症例では局所再発率が高率 であった（表11）、リンパ節転移との関係ではリ 
表10 局所再発と神経浸潤

\begin{tabular}{l|c|c|ccc|cc}
\hline & & & \multicolumn{3}{|c|}{ 浸潤程度 } & \multicolumn{2}{c}{ 浸潤形式 } \\
\cline { 2 - 8 } & NI (-) & NI $(+)$ & NI 1 & NI2 & NI 3 & INI & PNI \\
\hline 局所再発 $(+)$ & $12(14.0 \%)$ & $12(37.5 \%)$ & 8 & 2 & 2 & 8 & 4 \\
局所再発 (-) & $74(86.0 \%)$ & $20(62.5 \%)$ & 12 & 4 & 4 & 17 & 3 \\
\hline
\end{tabular}

表11 局所再発症例における壁哚達度と神経浸潤

\begin{tabular}{c|c|c|c|c}
\hline & sm以下 & pm & ss & s 以上 \\
\hline NI $(+)$ & 0 & $1 / 4(25.0 \%)$ & $4 / 10(40.0 \%)$ & $7 / 18(38.9 \%)$ \\
NI $(-)$ & $0 / 10$ & $2 / 32(6.3 \%)$ & $6 / 24(25.0 \%)$ & $4 / 20(20.0 \%)$ \\
\hline
\end{tabular}

表12 局所再発症例におけるリンパ節転移と神経浸潤

\begin{tabular}{ccc}
\hline & $\mathrm{n}(+)$ & $\mathrm{n}(-)$ \\
\hline $\mathrm{NI}(+)$ & $10 / 22(45.5 \%)$ & $2 / 10(20.0 \%)$ \\
$\mathrm{NI}(-)$ & $5 / 27(18.5 \%)$ & $7 / 59(11.9 \%)$ \\
\hline
\end{tabular}

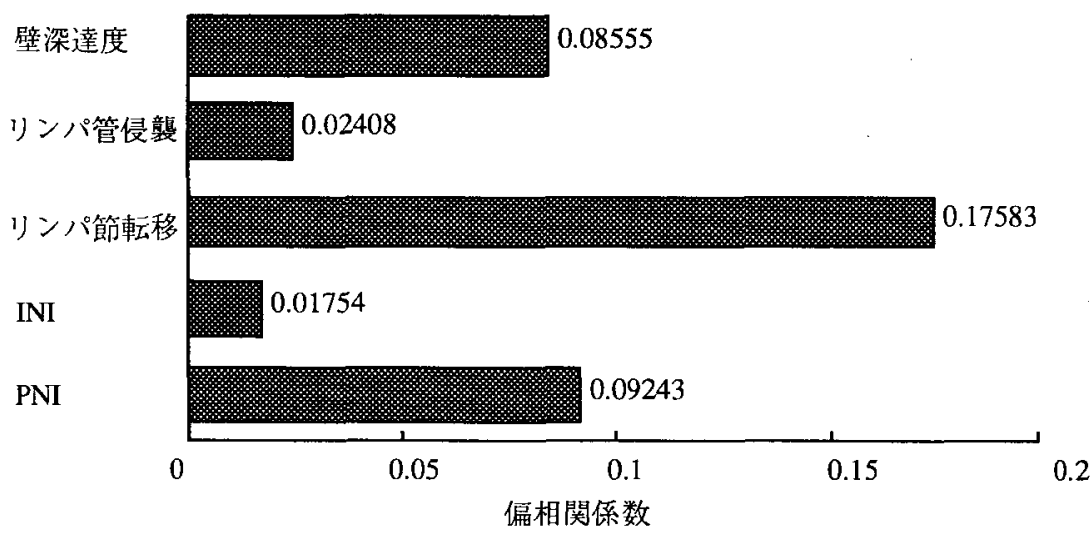

図 4 局所再発に関する偏相関係数

ンパ節転移陽性群において，神経浸潤を認めない 場合の局所再発率27例中 5 例（18.5\%）に比べ, 神経浸潤を認めた場合には22例中10例（45.5\%） と有意に高率であった（ $\mathrm{p}<0.05 ）($ 表12）.

壁深達度, リンパ節転移, 神経浸潤, および神 経浸潤とかかわりの強いリンパ管侵襲について局 所再発との関係を偏相関分析により検討する之, リンパ節転移の偏相関係数が最も高く 0.17583 , ついで PNI の0.09243で, 壁潹達度より神経周囲 間隙浸潤のほうが局所再発において強いかかわり をむっていた（図4）。

\section{(4) 累積生存率}

5 年累積生存率は神経浸潤陽性群では62.5\%, 陰性群では $90.7 \%$ であり陽性群において有意に生

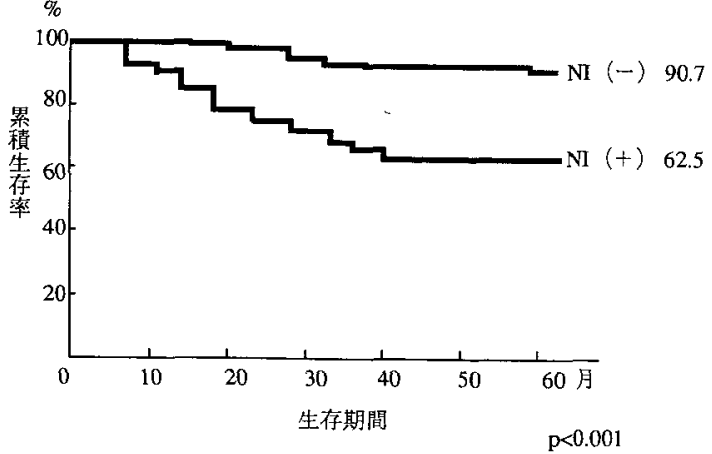

図 5 累積生存率

存率は低下した $(\mathrm{p}<0.001)$ （図 5$)$ ）壁深達度 と神経浸潤の有無により生存率を検討したとこ ろ，ss 以上の症例において神経浸潤を認めない 


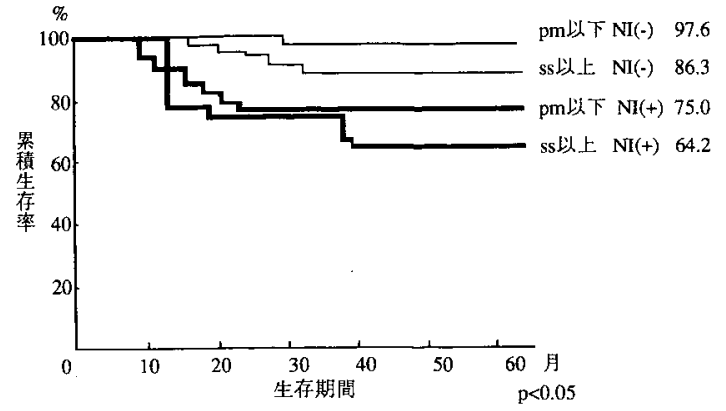

図 6 壁深達度と累積生存率

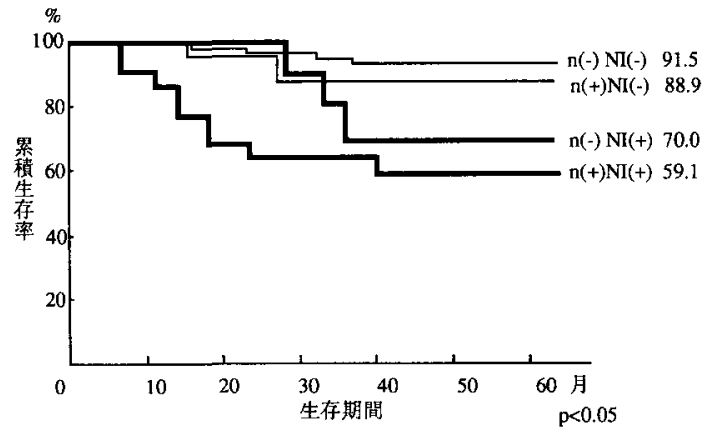

図７リンハ節転移と累䄼生存率

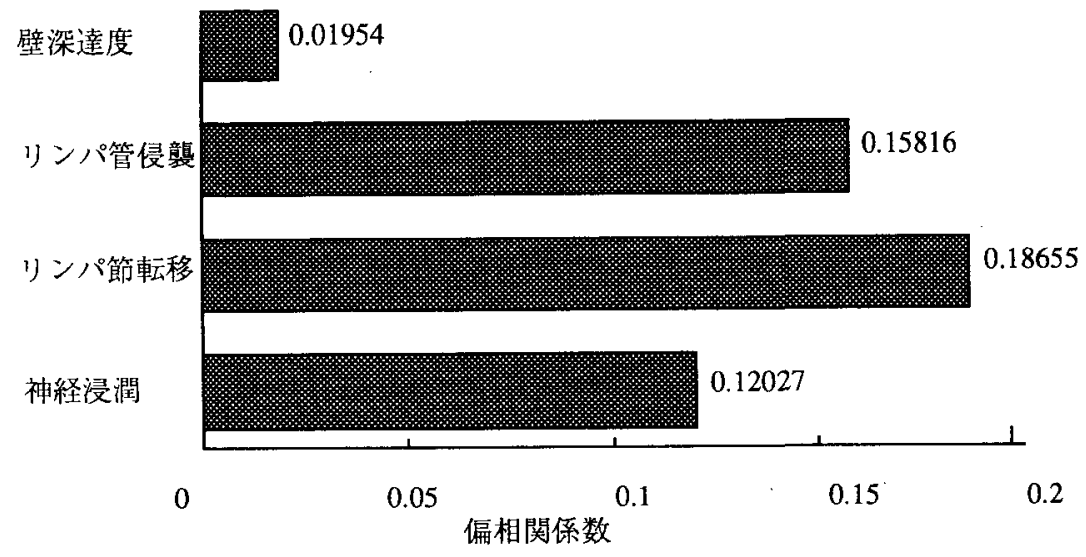

図 8 生存期間に関する偏相関係数

場合の生存率は $86.3 \%$ あるるのに対し，認めた場 合では64. $2 \%$ と有意に神経浸潤陽性例において生 存率の低下がみられ，pm 以下においても同様の 結果であった（ $\mathrm{p}<0.05 ）($ 図6 6 ）。リンパ節転移 の有無により神経浸潤陽性と狯性とを比較したよ ころ，リンパ節転移陽性症例における神経浸潤陽 性群の生存率が59.1\%であるのに対し，陰性群で は88.9\%であり神経浸潤を認めた場合には有意に 生存率の低下が認められた $(\mathrm{p}<0.05)$ 。またり ンパ節転移陰性症例における神経浸潤陽性群の生 存率は $70.0 \%$ であるのに対し，陰性群は $91.5 \%$ で ありリンパ節転移陰性群においても神経浸潤を認 めた場合, 有意に生存率は低下した（ $p<0.05 ）$ (図 7 ).

生存期間と先の各因子との関係を偏相関分析で 検討すると, 各因子の偏相関係数から生存期間に 相関する要因は,リンパ節転移が最も高く 0.18655 , ついでリンパ管侵襲の 0.15816 , 神経浸潤の
0.12027であった（図 8 ）。

\section{III. 考 察}

癌細胞の神経浸潤は，1835年にCruveilhier に より報告されたのが最初である1)。さらに1905年 に Ernstにより癌の進展様式のひとつとして報 告された2)。神経浸潤に関しては神経叢が密に分 布している膵癌や胆管癌で比較的多く研究されて (るが3-6)，膵癌における後腹膜腔局所再発に神 経浸潤が関係しているのではないかと考えられ， 組織学的に癌細胞が神経束に沿って進展していく 様子がとらえられている77。直腸癌における神経 浸潤に関する報告は1943年に Seefeld らによりな されたのが最初であり，直腸癌の約30\%に認めら れた之述へている ${ }^{8}$ ，その後直腸癌における神経 浸潤に関する報告はわずかであったが, 近年自律 神経温存術式が普及するにしたがい，神経への癌 細胞の浸潤に関して関心が持たれるようになり, 
神経浸潤に関する研究が行われるようになってき た ${ }^{9-12)}$ 。また自律神経の温存にともないその周囲 に残されるリンパ節への転移の有無に関しても研 究され，遺残の可能性が報告されている13,14．

直腸癌における神経浸潤は諸家の報告による上 30\%前後に認められるといわれでいるが，今回の 検討では27.1\%であった．神経浸潤には神経線維 束内浸潤と神経周囲間隙浸潤とが，見られたが， 神経線維束内浸潤のほうが頻度が高く $21.2 \%$ ，神 経周井間隙浸潤は5.1\%であり，神経周囲間隙浸 潤では神経線維束内浸潤を伴っていることが多 かった．今回の検討では他因子の影響を除去する 目的で偏相関分析を行ったが，肉眼所見では肉眼 分類および環周度と, 病理組織学的所見ではリン パ管侵襲，壁深達度，リンパ節転移との相関関係 が強かった，神経浸潤の程度においては，リンパ 管侵襲およびリンパ節転移が強くなるにしたがい 神経浸潤の程度も増す傾向にあり，壁深達度にお いても浸潤が樑くなるに伴い神経浸潤の程度も強 くなった．浸潤形式ではリンパ管侵襲陽性および リンパ節転移陽性症例において神経周囲間隙浸潤 を多く認め, 病理組織学的所見からも神経浸潤と リンパ流との関係が示唆されたが，とくに神経周 囲間陌浸潤が何らかの関係をもっていると考えら れた.

再発に関しては神経浸潤を認める症例において 局所再発が多いと予想されたが，今回の検討でも $1 \%$ 以下の危険率で有意に神経浸潤を認めた場合 には局所再発の頻度が高かった。しかも，神経周 囲間隙浸潤を認める症例においてその頻度は高 く，偏相関分析からみても神経線維束内浸潤に対 して神経周井間隙浸潤は局所再発との相関関係を もっており，神経周国間隙浸潤のみられる症例で はより悪性度が高いと考えられた。このことより 直腸癌の根治術式として自律神経温存術を選択方 るにあたっては，神経浸潤の存在も考慮する必要 があると考えられた。

予後に関しては，神経浸潤陽性例で明らかに生 存率が低く，一般的に予後を左右すると考えられ ているリンパ節転移の有無上組み合わせてみる 上，リンパ節転移があっても神経浸潤のない群に 比しリンパ節転移がなくても神経浸潤を認める群 において生存率が低かった。また壁深達度との関 係ではss 以上で神経浸潤を認めない群に対し， pm 以下でも神経浸潤認めた場合において生存 率は低く神経浸潤は重要な予後規定因子であると 上考えられた。

今回の研究では腸管壁内における神経分布に限 定し検討した．しかし，一口に神経分布といって も，腸間膜を通って壁内に分布する神経は脈管と 密接な関係をもっており，漿膜下組織を通過した 後は, 固有筋層内の Auerbach 神経叢八之面状展 開を示す。ささらに，ここから粘膜下の Meissner 神経叢へと連なることになる、こうした神経の漿 膜側からの展開に対向する型で, 癌細胞は粘膜側 から侵入していくが, 癌細胞に有意な自動移動能 はないのでその移動には，リンパ管または血管流 に乗るか，粘膜筋板または固有筋層の筋細胞の収 縮に伴うもみこみ型組織液の移動に頼らざるを得 ない。リンパ管または血管流による場合，リンパ 流は末梢の動脈性毛細管の漏出液を静脈性毛細管 で収容できない余剩分として取り入れ，これが沿 血管，沿神経性に中枢側入次第に移動していくの が通則である，血管流に乗る場合はほとんどが静 脈路でかつ壁在血栓を生じやすく，多くの場合は 閉塞栓となり該当領域が領域的分画として循環系 より隔離されてしまう。粘膜筋板または固有筋層 の筋細胞の収縮に伴うもみこみ型の組織液の移動 による場合，粘膜から漿膜に向かう transmural flow は粘膜面に垂直（vertical）な脈路を経なけ ればならない，粘膜筋板，固有筋層周囲には水平 (horizontal) なリンパ路，脈路があり，それ が腫瘍増殖とともに容易に顕在化しやすいこと は，日常の観察事である。この両者を結合する型 でリンパ液流が形成され，その時利用されやすい のは，動脈周囲のリンパ路である，その中でこれ に随伴する神経は，血管やリンパ管に比し可伸展 に著しくそしい。こうしたことから，腫瘍増大に 伴う組織成分間の歪みは神経周囲において最大と なり，そこにリンパ流が高まる可能性が生じてく る.

ところで神経の構造は神経線維が集まりその周 囲を神経内膜がおおい1本の神経線維束となり， さらに外側を神経周膜にお拉わ机 1 本の神経と なっている，神経線維束と神経周膜との間は神経 周囲間隙亡いわれている，かつて神経周囲間隙之 
リンパ管とは交通性があるのではないかと考えら れていたが，Larson らはそれらには交通性のな いことを証明し15)，Hassan らは電子顕微鏡で観 察することにより脈管とは関係をもたずに，神経 の周囲に直接進展してきた癌細胞が神経周囲間隙 に浸潤し，神経周囲間隙とリンパ管と交通性がな いと報告している16)．Böch らによる色素を用い た研究によっても解剖学的, 機能的に交通性は否 定的之されている17)。しかしながら，神経周囲に はリンパ管が密に取り巻いており，神経浸潤とリ ンパ管とは何らかの関係がある上考えられる.今 回の検討でも神経浸潤とリンパ管侵襲との間には 密接な相関関係が認められた。また神経浸潤に は, 癌細胞が神経線維束内にはいりこれを破壊す るように浸潤している神経線維束内浸潤（INI） と，神経線維束と神経周膜との間に侵入するよう に浸潤している神経周囲間隙浸潤 (PNI) とが観 察された。神経周囲間吵浸潤では癌細胞が壊れた 神経周膜の一部，おそらく神経に分布する血管の 侵入部位と考えられるが，その破壊部位より神経 線維束と神経周膜との間の間隙に侵入し，その間 隙を埋めるように浸潤していくと考えられた．以 上の考察に基づき得られたデーターを分析する と, 癌の予後因子として神経浸潤, とりわけ神経 周囲間陌浸潤が強く効いているといえよう。神経 線維束内浸潤はこのリンパ流の involvement 性 PNI に対して，あくまで神経線維束の構造維持 の infegnity の度合の問題である。 また神経周囲 間隙浸潤に関しては膵癌において神経の中枢側へ 癌細胞が進展していく様子が観察されているが7, 直腸癌においても膵癌と同様に癌細胞がその 間隙を通り進展していくことが考えられる.今回 の検討でも，神経浸潤を認める症例において局所 再発が高頻度で認められ，とくに神経周囲間隙に 浸潤を認める症例で多く，予後においてもリンパ 節転移の有無にかかわらず神経浸潤を認める症例 で 5 年生存率が有意に低下していた。これより神 経浸潤は予後を予测するうえで重要な因子であ り，観察すべき因子のひとつといえるであろう． さらに，神経浸潤のなかでも神経線維束を圧迫， 破壊するように浸潤している神経線維束内浸潤に 比べ, 神経線維束と神経周膜との間隙への浸潤は 重要である．神経周囲間隙はリンパ管や静脈と同
様に癌細胞が進展していくひとつの進展経路であ ると考えられる，今後さらに直腸癌における神経 浸潤の進展に関して，また腸管壁外の神経組織へ の浸潤に関して検討を加える必要がある.

以上より神経浸潤は癌細胞の進展経路のひとつ であり，腸管壁内に神経浸潤を認めた場合骨盤神 経にも癌細胞の浸潤の可能性がある.とりわけ自 律神経温存術式を行った場合，神経浸潤のある症 例では残置組織に癌細胞が遺残する可能性が考え られ，神経浸潤の有無を自律神経温存術式の選択 基準として取り上げ，この術式の適応を神経周囲 間隙浸潤を認めない症例に限定すべきという見解 が成立するであろう。また神経浸潤を認めたとし てもごく軽度の症例とすべきである．現行の病理 組織学的因子を含めた場合, リンパ節転移を認め ない症例，神経浸潤なかでも神経周囲間隙浸潤を 認めない症例に適応を絞るのが妥当と考えられ た。

\section{IV. 結 語}

1）直腸癌の腸管壁内における神経浸潤は $27.1 \%$ に認められ，神経線維束内浸潤之神経周囲間隙浸 潤が認められた。

2) 神経浸潤には，肉眼所見では肉眼分類が最も 強い相関関係をもち, 病理組織学的所見ではリン パ管侵襲，壁深達度，リンパ節転移であった。

3 ) 局所再発について病理組織学的因子を比較す ると, リンパ節転移および神経周囲間隙浸潤に強 い相関関係を認めた。

4) 神経浸潤は予後に対し強い相関関係を持って おり，予後規定因子のひとつである.

本論文の要旨は第 42 回日本消化器外科学会総会にお いて発表した。

稿を終えるに臨み御指導, 御校閲を賜わりました浜 野恭一教授に感謝の意を捧げるとともに，直接御指導 頂きました龟岡信语助教授, 病院病理科河上牧夫教 授, 研究に御協力頂きました桜田実技師長に心よりの 謝意を表します。

\section{文献}

1) Cruveilheir $J$ : Maladies nes nerfs. Anatomic Pathologique du Dorps Humain, 2nd ed, pt 35, p 3, Paris, 1835, J B Bailliere

2) Ernst P: Über das wachstum und die 
verbreitung bösartiger geschwülste, insbesondere des krebses in den lymphbahnen der Nerven. Beitr Path Anat Supp $17: 29-50,1905$

3) 松田真佐男, 二村雄次 : 膵頭部癌におりる神経 周囲侵襲. 日外会誌 $84: 719-728,1983$

4) Pour PM : Patterns of growth and metastases of induced panceatic cancer in relation to the prognosis and its clinical implications. Gastroenterology $100: 529-$ 536, 1991

5) Bhuiya MR : Clinicopathologic studies on perineural invasion of bile duct carcinoma. Ann Surg 215 : 344-349, 1992

6）鈴木正徳, 高橋徹, 大内清昭ほか: 胆管癌にお ける神経周囲浸潤一その成立機序之臨床病理学 的意義について一, 癌の臨 $34: 2080-2090$, 1988

7）菅原正都：膵癌進展様式の臨床病理学的ならび に実験的研究一之くに萃外神経叢内神経浸潤に ついて一. 日消外会誌 21:1363-1372，1988

8 ) Seefeld PH, Bargen JA: The spread of carcinoma of the rectum: Invasion of lymphatics, veins and nerves. Ann Surg $118: 76-90,1943$

9 ）白水和雄, 磯本浩晴, 掛川暉夫 : 直腸癌の神経 周囲侵襲に関する臨床病理学的研究一特に予後 および自律神経温存術之の関連性一。日外会誌
$92: 411-418,1991$

10）二渡久智, 落合正宏, 舟戋孝彦: 大腸癌におけ る神経周囲浸潤の検討. 日本入腸肛門病会誌 $44: 1054-1060,1991$

11）永澤康滋, 柳田謙蔵, 辻田和紀 : 直腸癌症例の 神経浸潤について一特に臨床的病理学検討一。 日消外会誌 $24: 1022-1028,1991$

12）河原秀次郎：下部直腸癌進展形式の臨床病理学 的検討. 日本大腸肛門病会誌 $45: 377-383$, 1992

13）前田耕太郎, 橋本光正, 山本修美： s 状結腸 癌, 直腸癌における神経周囲浸潤と自律神経お よび周囲組織への転移に関する検討，日消外会 誌 $26: 590,1993$

14）山腰英紀, 大木繁男, 今井信介：進行直腸癌に 対する自律神経温存手術による癌細胞遗残につ いての病理学的検討. 日消外会誌 $26: 591$, 1993

15) Larson DL, Roberts DK, et al : Perineural lymphatics: Myth or fact. Am J Surg $112: 488-492,1966$

16) Hassan MO, Maksem $J$ : The prostatic perineural space and its relation to tumor spread. Am J Surg Pathol 4 : 143-148, 1980

17) Böch $P$, Hanak $H$ : Die verteilung exogen er peroxydase im endoneuralraum. Histochemie $25: 361-371,1971$ 


\title{
Histopathological Assessment Regarding Nerve Infiltration In Rectal Cancer
}

\author{
K. Suzuki \\ Department of Surgery II , \\ Tokyo Women'S Medical College, Tokyo \\ (Director : Prof. Kyoichi Hamano)
}

It it generally considered that a progressive mode via the nervous system is existent other than that of the vascular system in rectal cancer, and a histopathological assessment has been made regarding nerve infiltration in 118 cases of rectal cancer. Nerve infiltration was observed in $27.1 \%$ as classified as infiltration in nerve fascicle and infiltration in the perineural interstice. As a result of assessing the relationship of nerve infiltration and other factors by partial correlation analysis, the macroscopic classification was seen to have a strong correlation by macroscopic finding. By histopathological finding, lymphatic vessel invation and lymph node metastasis had a strong correlation, suggesting the relation ship exists between nerve infiltration and lymphatic flow. Regarding local recurrence, a significantly high frequency of $37.5 \%$ was observed in nerve infiltration-positive cases, compared with $14.0 \%$ in nerve infiltration-negative cases $(p<0.01$ ), and the frequency was particularly high in the perineural interstice infiltration-positive cases. The survival rate was significantly low in nerve infiltration-positive cases $(p<0.001)$ and also low in nerve infiltration-positive cases even when no lymph node metastasis was observed, from which nerve infiltration was considered to be one of the prognosis-specifying factors. 